\title{
The composition and diversity of plant species in pasak bumi's (Eurycoma longifolia) habitat in Batang Lubu Sutam forest, North Sumatra, Indonesia
}

\author{
ARIDA SUSILOWATI ${ }^{1, \boldsymbol{v}}$, HENTI HENDALASTUTI RACHMAT ${ }^{2}$, DENI ELFIATI ${ }^{1}$, M. HABIBI HASIBUAN ${ }^{1}$ \\ ${ }^{1}$ Faculty of Forestry, Universitas Sumatera Utara. Jl. Tridharma Ujung No.1 Kampus USU, Medan 20155, North Sumatra, Indonesia. \\ Tel./fax.: + 62-61-8220605 ”email: arida_iswanto@yahoo.co.id \\ ${ }^{2}$ Forest Research, Development and Innovation, Ministry of Environment and Forestry. Jl. Raya Gunung Batu 5 Bogor 16610, West Java, Indonesia
}

Manuscript received: 6 October 2018. Revision accepted: 21 January 2019.

\begin{abstract}
Susilowati A, Rachmat HH, Elfiati D, Hasibuan MH. 2019. The composition and diversity of plant species in pasak bumi's (Eurycoma longifolia) habitat in Batang Lubu Sutam forest, North Sumatra, Indonesia. Biodiversitas 20: 413-418. Pasak bumi (Eurycoma longifolia Jack) is one of the most popular medicinal plants in Indonesia. Currently, E. longifolia is being over-exploited due to its potential and popularity as herbal medicine and its high value in the market. Therefore, the study on the population structure of the species and habitat characterization is required to ensure successfulness of conservation of this species. The study was carried out in lowland forest, located in Limited Production Forest within the Register Number 40, situated administratively in Papaso Village, SubDistrict of Batang Lubu Sutam-Padang Lawas, North Sumatra, Indonesia. Batang Lubu Sutam forest is known as a source of pasak bumi material in North Sumatra. Every year tons of pasak bumi are collected from this forest and exported to Malaysia and surrounding countries. Due to illegal harvesting for its roots, pasak bumi has been seriously depleted in some areas in Batang Lubu Sutam forest. Therefore, current data on its population are needed for conservation effort of Batang Lubu Sutam's pasak bumi. The objectives of this study were to assess the structure of forest where pasak bumi grows and to determine the correct management for sustainability the future stocks. Vegetation analysis was carried out purposively in four transect belts, each consisting of five quadrats or plots. The results showed that the Importance Value Index of pasak bumi at seedling, sapling, pole and tree stages was $21.26 \%, 9.147 \%$, 0 , and 0 respectively. The Shannon Diversity Index $(\mathrm{H})$ ranged between 3.050 and 3.220 and was inside its common value distribution. The evenness index was high, more than 0.85 , at all stages of plant growth. The disappearance of pasak bumi at pole and tree stages indicates threatening condition for the sustainability of pasak bumi in the study sites because of excessive harvesting.
\end{abstract}

Keywords: Composition, diversity, pasak bumi, species

\section{INTRODUCTION}

Eurycoma longifolia Jack (known as pasak bumi in Indonesia) is a flowering plant of the family Simaroubaceae, native to Indonesia, Malaysia, Vietnam, Cambodia, Myanmar, Laos and Thailand (Patwardhan et al. 2004; Baht and Karim 2010; AbdRahman et al. 2002; Chua et al. 2005). E. longifolia grows naturally in most part of Sumatra and Kalimantan Islands (Heyne 1950) and is commonly traded in both islands. It has long been known for its medicinal uses among traditional people all over Indonesia.

Eurycoma longifolia is a shrubby tree which grows in sandy soil. It has tall and slender stem with green pinnate leaves. The numerous leaflets are opposite or sub-opposite, lanceolate to ovate-lanceolate, $5-20 \mathrm{~cm}$ by $1.5-6 \mathrm{~cm}$, with smooth margins. The flowers are tiny, reddish, unisexual and are densely arranged. The plant belongs to the Simaroubaceae family (Keng and Keng 1990; Goh et al. 1995).

Eurycoma longifolia is one of the most popular folk medicines for its aphrodisiac effects and treatment of intermittent fever (malaria) (Jiwajinda et al. 2001). The root extract of $E$. longifolia is mostly used as folk medicine for health problems such as sexual dysfunction, aging, malaria, cancer, diabetes, anxiety, aches, constipation, exercise injury, fever, lack of energy, leukemia, and osteoporosis (Kuo et al. 2004; Hussein et al. 2007; Fiaschetti et al. 2010). Many studies also reported the pharmacological benefits of $E$. longifolia for male fertility enhancement (Teh et al. 2011; Low et al. 2013; Chen et al. 2015), and to cure malaria (Chan et al. 1986; Kardono et al. 1991; Low et al. 2011; Wandsforter et al. 2010), cytotoxicity (Kuo et al. 2003), microbially-caused diseases (Faraouk et al. 2008; Kong et al. 2014), inflammatory (Tran et al. 2014), diabetes (Husen et al. 2004; Lahrita et al. 2015), and osteoporosis (Melton et al. 2005).

The very high price of E. longifolia has been the main trigger of high-level exploitation since current harvesting relies only on wild harvesting of E. longifolia Jack by pulling out the roots. Destructive harvesting by root pulling should become a concern for the plant's sustainability (Farouk et al. 2007). There is a lack of research related to its natural habitat preferences, whereas, the external factors of disturbance such as destructive harvesting, suddenly change the composition of plant structures. There is a lack of information on habitat, tree composition and diversity of Batang Lubu Sutam forest. Therefore, the objectives of this 
research were to assess the structure of forest where $E$. longifolia Jack grows and to determine the correct management for the sustainability of the future stocks.

\section{MATERIALS AND METHODS}

\section{Study area}

The study was located in Limited Production Forest (Hutan Produksi Terbatas) Torsipara-para, the register Number 40, administratively located within Papaso Village, Batang Lubu Sutam Sub-district, Padang Lawas District, North Sumatra, Indonesia. This is a border area between North Sumatra Province and Riau Province (Figure 1). The remaining forested area is only $500 \mathrm{ha}$. The altitudes of the research site range between $250-700 \mathrm{~m}$, with temperature of $27-30^{\circ} \mathrm{C}$ and relative humidity around $65-90 \%$.

\section{Data collection}

Vegetation analysis was carried out in four transect belts, each consisting of five quadrats or plots. As generally conducted for rare species, the locations of transects were determined purposively, based on local people information of the occurrence of E. longifolia in certain sites of Torsipara-para forest (Jumawan et al. 2015). The starting point of the plot in each of the transect belts was located at the minimum altitude of $250 \mathrm{~m}$. and this was based on the knowledge of indigenous people that the species had never been found below that altitude. The distance between transect belts varied between 100 and 300 meters, while the size of each sampling quadrat was $2 \times 2 \mathrm{~m}, 5 \times 5 \mathrm{~m}, 10 \times 10$ $\mathrm{m}$ and $20 \times 20 \mathrm{~m}$ each for seedling, sapling, pole, and tree respectively. The observed variables for each growth stage were as follows: (i) Seedling stage: species, number of individual for each of the species, (ii) Sapling stage: species, number of individual for each of the species, (iii) Pole stage: species, dbh, height, number of individual for each of the species, (iv) Tree stage: species, dbh, height, number of individual for each of the species

\section{Data analyses}

The vegetation data were analyzed to calculate relative density, frequency, abundance, and dominance of the species; and from those values, the Importance Value Indices (IVI) were calculated. To express the dominance and biological success of any species with a single value, the concept of Importance Value Index (IVI) has been developed by Curtis and McIntosh (1950), Phillips (1959) and Misra (1968). Rastogi (1999) and Sharma (2003) reported the IVI as a better expression of the relative ecological importance of a species than an absolute measure such as frequency, density or dominance.

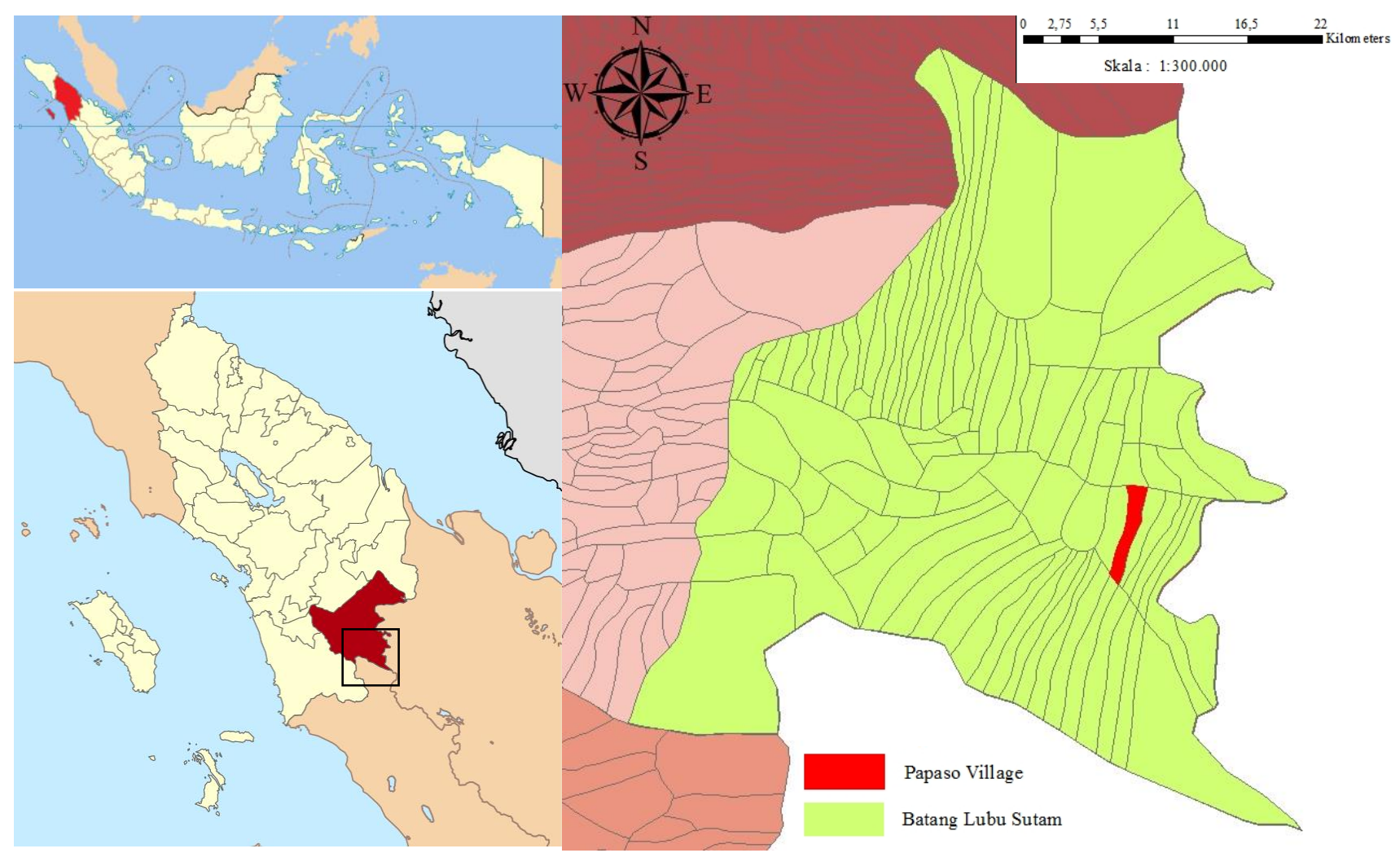

Figure 1. Research location in Papaso Village, Batang Lubu Sutam Sub-district, Padang Lawas District, North Sumatra, Indonesia 
Relative density

Density denotes the average number of individuals of a given species out of the total of samples examined in a study area (Oosting 1942; Rastogi 1999; Sharma 2003). The Relative Density (RD) was calculated using the formula:

$$
\mathrm{RD}=\frac{\text { total number of individuals of a species }}{\text { total number of all individuals of all species }} \times 100 \%
$$

\section{Relative frequency}

Frequency indicates the number of sampling plots (sites) in which a given species occurs as a percentage of all sampling plots and based on the presence or absence of a species (Raunkaier 1934; Rastogi 1999; Sharma 2003). Relative Frequency (RF) was calculated using the formula:

$$
\mathrm{RF}=\frac{\text { frequency of a species }}{\text { frequency of all species }} \times 100 \%
$$

\section{Relative dominance or relative basal area $(R B A)$}

Relative basal area

Dominance is defined as the sum of basal areas of all individuals of a species. The basal area refers to the ground covered by the stems (Rastogi 1999; Sharma 2003). Relative Basal Area (RBA) is calculated using the formula:

$$
\mathrm{RBA}=\frac{\text { basal area of a species }}{\text { total basal area of all species }} \times 100 \%
$$

\section{Importance value index (IVI)}

IVI was calculated with this formula:

$\mathrm{IVI}=\mathrm{RD}+\mathrm{RF}$ (For seedling and sapling stage).

$\mathrm{IVI}=\mathrm{RD}+\mathrm{RF}+\mathrm{RBA}$ (for pole and tree).

Importance percentage was obtained by dividing the IVI value by 3 .

\section{Species diversity}

The species diversity determined using ShannonWiener index (Shannon and Wiener 1963):

$$
\mathrm{H}^{\prime}=\sum \text { pi ln pi }
$$

Where, pi is the proportion of individuals of $i^{\text {th }}$ species and individuals of all the species in a stand. The equitability or species per log cycle index was determined following Whittaker (1972): $E=S /\left(\log n_{i-} \log n_{s}\right)$. Where $\mathrm{S}$ is the number of species in that stand and $\mathrm{n}_{\mathrm{i}}$ and $\mathrm{n}_{\mathrm{s}}$ are the density value of most and least important species, respectively.

\section{RESULTS AND DISCUSSION}

\section{Species composition}

The tree species composition of forest reflect the complex ecological conditions of the particular site. In natural forest, the composition is heterogenous resulted from relationship of different ecological requirement of individual tree species, different growth capabilities and different physical ages each species could reach (Saniga and Balanda 2008). E. longifolia Jack has a wide range of altitudes. Based on the physical condition in each plot, in general, E. longifolia Jack was found at elevation between 280-700 m asl, where it tended to increase with elevation. According to the collection material found in Herbarium Bogoriense, E. longifolia Jack can be found at elevations of 0-700 $\mathrm{m}$ asl. The elevation affects climatic factors, namely temperature, relative humidity, rainfall and sunlight intensity. This combined climatic factors will affect species distribution (Ewusie 1990). The daily observation on climatic condition of research location showed that temperature condition ranged between $27-30^{\circ} \mathrm{C}$ and the relative humidity ranged between $60-89 \%$. Table 1 shows only plant species having IVI higher than 10 . In seedling stage, it was found that E. longifolia had the highest IVI.

In all seedling plots, we found 41 species. In this stage, pasak bumi was the dominant species in the location. Our observation showed that the pasak bumi seedlings were distributed in clumps and commonly found close to the

\begin{tabular}{|c|c|c|c|c|}
\hline Species & RD & $\mathbf{R F}$ & RBA & IVI \\
\hline \multicolumn{5}{|l|}{ Seedling stage } \\
\hline Eurycoma longifolia & 10.15 & 11.11 & & 21.26 \\
\hline Antocephalus sp. & 11.21 & 8.64 & & 19.85 \\
\hline Streblus elongatus & 10.15 & 7.41 & & 17.56 \\
\hline Vatica nitens & 8.67 & 7.41 & & 16.08 \\
\hline Rao-rao & 6.34 & 5.56 & & 11.90 \\
\hline Anisoptera megistocarpa & 5.71 & 6.17 & & 11.88 \\
\hline Meranti bosi & 5.29 & 4.94 & & 10.23 \\
\hline \multicolumn{5}{|l|}{ Sapling stage } \\
\hline Antocephalus sp & 14.39 & 8.78 & & 23.17 \\
\hline Streblus elongatus & 9.91 & 8.11 & & 18.02 \\
\hline Vatica nitens & 8.5 & 8.78 & & 17.28 \\
\hline Anisotera megistocarpa & 6.6 & 6.08 & & 12.68 \\
\hline Rao-rao & 4.95 & 5.42 & & 10.37 \\
\hline Meranti bosi & 4.73 & 4.95 & & 9.68 \\
\hline Ubahan & 4.73 & 4.72 & & 9.45 \\
\hline Eurycoma longifolia & 6.08 & 3.07 & & 9.15 \\
\hline \multicolumn{5}{|l|}{ Pole stage } \\
\hline Anthocephalus sp & 17.01 & 10.57 & 3.98 & 31.56 \\
\hline Streblus elongatus & 8.62 & 8.06 & 3.94 & 20.62 \\
\hline Vatica nitens & 7.33 & 7.26 & 3.66 & 18.24 \\
\hline Meranti bosi & 6.03 & 5.65 & 3.58 & 15.26 \\
\hline Rao-rao & 6.03 & 4.84 & 3.50 & 14.38 \\
\hline Anisoptera megistocarpa & 5.60 & 4.03 & 3.58 & 13.22 \\
\hline \multicolumn{5}{|l|}{ Tree stage } \\
\hline Anthoceplahus sp & 14.92 & 10.37 & 2.79 & 28.08 \\
\hline Anisoptera megistocarpa & 7.66 & 7.41 & 2.81 & 17.88 \\
\hline Streblus elongatus & 5.65 & 8.15 & 3.98 & 17.77 \\
\hline Rao-rao & 7.26 & 7.41 & 2.98 & 17.65 \\
\hline Meranti bosi & 7.26 & 5.93 & 3.07 & 16.26 \\
\hline Vatica nitens & 12.90 & 0.74 & 2.46 & 16.10 \\
\hline
\end{tabular}
mother trees (Figure 2).

Table 1. Top Importance Value Index / IVI (> 10.0) of different species at different stages of study site 


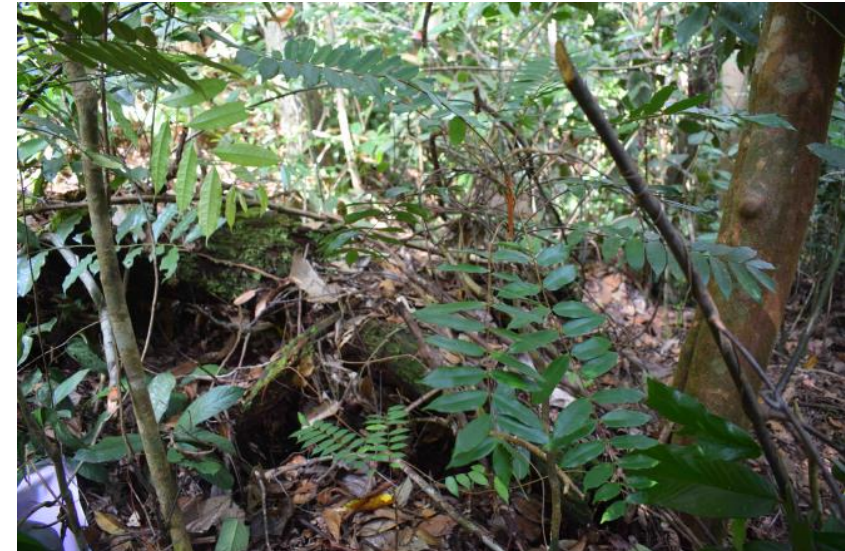

Figure 2. Eurycoma longifolia seedling grown near its harvested mother trees

Regardless of the effect of environmental and competition factors, this result was relevant to the conclusion that distribution pattern of plant species is usually clumped since the seeds fall close to their parents. According to Ashton (1969), the clumping of individuals of a species may be due to insufficient mode of seed dispersal. Okuda et al. (1997) also stated that clumped distribution of seedlings might be caused by lower number of seed and seedling predators and low species mortality rates. The clumped pattern of pasak bumi seedling is also related to seed dispersal and its reproductive system. Pasak bumi is dioeceous plant, with male and female flowers, occur in different plants (Corner 1988). Male trees have sterile pistil and produce seeds that fall before maturity. Female trees are able to produce seeds but have steril stamens. The pollination process occurs through cross-pollination and is probably mediated by insects (Padua et al. 1999).

Seed dispersal is critical in seedling recruitment stage which is influenced by some factors such as pollinator condition, movement of pollinators, distance, magnitude of pollen and landscape condition (Hamrick and Trapnell 2011; Garcia et al. 2007; Nathan and Muller-Nandhu 2000). Pasak bumi seed is heavy with weight average of $0.29 \mathrm{~g}$ and diameter of $0.5-0.7 \mathrm{~cm}$. The seeds are dispersed near the mother trees and the surviving seeds will grow into seedlings. There is no report about seed dispersal of pasak bumi but previous research reported that wind is probably the agent of pasak bumi seed dispersal. The bitter endocarp covering the seed may cause the limitation on seed dispersal agents. Due to this condition, the seeds were dispersed in clumps under the mother trees.

In sapling stage 35 species were found. Unlike that in seedling, the IVI of E.longifolia at sapling stage wet down to $8^{\text {th }}$ rank. As expected, there was no record of $E$. longifolia for pole and tree stages as the species is mostly a shrub. Pole and tree stages in the study sites was dominated by species within the group of Dipterocarps. The IVI of $E$. longifolia at seedling and sapling stages decreased significantly from the highest to the $8^{\text {th }}$. Similar result was also obtained by Kartikawati et al. (2014) in Kubu Raya district and Hasibuan et al. (2016) in Rumbio Forest who found that at the seedling stage E. longifolia was abundant but decreased significantly in sapling and mature stages. However, in certain sites, there is an exception that $E$. longifolia may grow to a "giant" size, where the species may reach more than $20 \mathrm{~cm}$ in diameter and more than $7 \mathrm{~m}$ in height.

In pole and tree stages, pasak bumi disappeared in our research location. This condition may be caused by the excessive harvesting of the mature E.longifolia that does not allow the species to be the most abundant in this stage. Based on the interviews with local people, in Tor siparapara forest, pasak bumi roots were commonly harvested at sapling and pole stages. The same case also occurred in Rumbio forest, Riau according to Hasibuan et al. (2016). According to Zulfahmi et al. (2015), another factor that explains the low number of sapling and pole stages is the high demand for this product. Local people prefer to collect the plant at sapling and pole stages due to its high price. The dry product has quite high price in the market. Kartikawati (2014) described that in 2013, the exporter of E. longifolia based in Deli Serdang got USD249.16 for a kilogram of chopped roots. Meanwhile, the price for 1: 200 extracts were USD3242.85 kg-1 and for 1: 50 extracts was USD1625 $\mathrm{kg}^{-1}$. The price had increased from the previous year, 2012, which was USD375 $\mathrm{kg}^{-1}$ for 1: 50 extracts and USD900 $\mathrm{kg}^{-1}$ for 1: 200 extracts. Such high price has encouraged the increased exploitation of E. longifolia Jack in the forest since current harvesting relies only on wild $E$. longifolia Jack by pulling out the roots. Destructive harvesting by root pulling should become a concern for the plant's sustainability (Farooquee et al 2004; Kala et al 2004; Ghimire et al. 2005).

The density of pasak bumi in our research site was low. The decrease in abundance from seedling stage to mature stage would influence the sustainability of its natural regeneration and the existence of pollinators. According to Lazuriaga et al. (2006), the age distribution in a population will influence its reproduction, pollinator behavior, mating ratio and the number of seeds produced. Many frugivores either decline in abundance or disappear from logged patches due to loss of habitat or changes in the abundance and quality of food sources (Jhonson 1998). Frugivores are important seed dispersers and affect the spatial patterns of plant recruitment (Howe and Smallwood 1982). The loss of frugivorous dispersers can alter tree community composition (Bohning 2001) and its natural regeneration. To avoid total loss of the species, ex situ conservation of genetic material of E. longifolia from the study area is compulsory. On the other hand, in situ conservation is not recommended since the forest is not a conservation area and the risk of illegal harvesting is high.

According to Odum (1971), natural regeneration status of tree species of any forest is determined on the basis of densities of seedlings and saplings. The ratio of various age groups in a population determines the reproductive status of the population and indicates the future course. Pasak bumi which was present only at seedling and sapling stages in our location were new entrants to the forest species composition. These are examples of discontinuous population structures (Brokaw 1987). 
Table 2. Species diversity, evenness, and species richness indexes for four plant growth stages in Torsipara-para Forest

\begin{tabular}{lccc}
\hline $\begin{array}{l}\text { Plant } \\
\text { growth } \\
\text { stage }\end{array}$ & $\begin{array}{c}\text { Species } \\
\text { diversity } \\
\text { index }\left(\mathbf{H}^{\prime}\right)\end{array}$ & $\begin{array}{c}\text { Species } \\
\text { evenness } \\
\text { index }\end{array}$ & $\begin{array}{c}\text { Species } \\
\text { richness index }\end{array}$ \\
\hline Seedling & 3.160 & 0.851 & 6.494 \\
Sapling & 3.220 & 0.851 & 7.108 \\
Pole & 3.080 & 0.873 & 6.017 \\
Tree & 3.050 & 0.851 & 6.362 \\
\hline
\end{tabular}

\section{Species diversity}

According to Wilsey and Sterling (2007), the term of diversity has two basic components: richness (number of species in a given area) and evenness (how relative abundance or biomass is distributed among species). The value is quantitatively described using index and varies depending on the forest condition. Biotic, abiotic and anthropogenic disturbances will influence the diversity of forest and influence the index value. Species diversity and richness of a site experiencing disturbances, therefore, will be a cumulative outcome of differential responses of species to disturbances. Some species may tolerate the disturbances and the others may disappear. However, the case of E. longifolia disappearance in Batang Lubu Forest is not the case of the species intolerance to disturbances, since the nature of disturbance is anthropogenic. The diversity index is also an indicator that integrates species richness and the abundance of individuals of each species and reflects the degree of heterogeneity or stability of vegetation (Anbarashan and Parthasaranthy 2013). The values of diversity, evenness and richness indexes in Torsipara-para Forest are described in Table 2.

In most of ecological studies, the value for Shanon diversity Index $\left(\mathrm{H}^{\prime}\right)$ is generally between 1.5 and 3.5. In this study, the values ranged from 3.050 to 3.220 and were inside its common value distribution. The value of diversity index can indicate the level of diversity in forest. Higher value of $\mathrm{H}^{\prime}$ indicates that the species diversity in the location is high. Odum (1971) states that species diversity tends to be high in older and younger communities in the newly formed forest community.

Species evenness index indicates how evenly the individuals of every species are distributed in a community. The value ranges from near 0 when most individuals belong to a few species to close to 1 when species are nearly equally abundant. The data above indicated that the evenness index was high, more than 0.85 , at all plant growth stages and there were no dominant species found in the location. Evenness index will be maximal if all species have the same number of individuals at each location. This condition is very rarely found in nature, because each species has specific ability for adaptation and tolerance, as well as life history. In addition, environmental conditions in nature are very complex.

From the study results, it was also found that Limited Production Forest status in the study area contained various economically valuable timber species. However, its status as Limited Production Forest has allowed timber and non- timber extraction within the area. Thus, the status may allow people to extract $E$. longofilia.

\section{ACKNOWLEDGEMENTS}

This research was part of Eurycoma longifolia research funded by TALENTA Universitas Sumatera Utara 2018 No. 2590/UN5.1.R/PPM/2018. Many sincere thanks for local farmer in Batang Lubu Sutam for their assistance for this research.

\section{REFERENCES}

Abd Rahman K, Niiyama K, Azizi, R, Appanah S, Lida S. Species assembly and site preference of tree species in a primary Seraya-ridge forest of Peninsular Malaysia. J Trop For Sci 14: 287-303.

Anbarashan M, Parthasarathy N. 2013. Diversity and ecology of lianas in tropical dry evergreen forests on the Coromandel Coast of India under various disturbance regimes. Flora 208: 22-32

Ashton PS.1969. Speciation among tropical forest trees: some deductions in light of recent evidence. Biol J Linn Soc 1: 155-196.

Bleher B, Böhning-Gaese K. 2001. Consequences of frugivore diversity for seed dispersal, seedling establishment and the spatial pattern of seedlings and trees. Oecologia 129: 385-394

Bhat R, Karim A. Tongkat Ali (Eurycoma longifolia Jack): A review on its ethnobotany and pharmacological importance. Fitoterapia 81: 669679.

Brokaw NVL. 1987. Gap-phase regeneration of three pioneer tree species in a tropical forest. J Ecol 75: 1: 9-19.

Chan KL, O'Neill MJ, Phillipson JD, Warhurst DC. 1986. Plants as sources of antimalarial drugs. Part 31 Eurycoma longifolia. Planta Med 52: 105-107.

Chen Y, Phang WM, Mu AKW, Chan CK, Low BS, Sasidharan S, Chan KL. Decreased expression of alpha-2-HS glycoprotein in the sera of rats treated with Eurycoma longifolia extract. Front. Pharmacol 6.

Chua L, Kamarudin S, Markandan M, Hamidah M. 2005. A preliminary checklist of vascular plants from the Machinchang Range, Pulau Langkawi, Peninsular Malaysia. Malay Nat J 57: 155-172.

Corner EJH. 1988. Wayside trees of Malaya Vol II. United Selangor Press, Kuala Lumpur.

Ewusie JP. 1986. Introduction to Tropical Ecology. Institute of Technology Bandung Press, Bandung.

Farouk AE, Benafri A. 2007. Antibacterial activity of Eurycoma longifolia Jack. A Malaysian medicinal plant. Saudi Med J 28: 1422-1424.

Farouk AE, Nawi M, Hassan S. 2008. Antibacterial peptides fromEurycomaa longifolia (Tongkat Ali) and Labisia pumila (Kacip Fatimah) leaves in Malaysia. Sci Brun 9: 55-63.

Fiaschetti G, Grotzer M, Shalaby T, Castelletti D, Arcaro A. 2010. Quassinoids: From traditional drugs to new cancer therapeutics. Curr Med Chem 18: 316-328

Garcia C, Gordano P, Godoy JA. 2007. Contemporary pollen and seed dispersal on Prunus mahaleb population: pattern and distance direction. Mol Ecol 16: 1947-1955

Goh SH, Chuah C, Mok J, Soepadmo E. 1995. Malaysian Medicinal Plants for the Treatment of Cardiovascular Diseases. Pelanduk Publications: Petaling Jaya, Malaysia,

Hamrick JL, Trapnell DW. 2011. Using population genetic analyses to understand seed dispersal pattern. Acta Oecologica 37: 641-649

Hasibuan S, Suhesti E, Insusanti E. 2016. Kajian ekologi pasak bumi Eurycomaa longifolia jack) dan pemanfaata nole hmasyarakat di sekitar hutan larangan adat Rumbio, Kabupaten Kampar, Provinsi Riau. Wahana Forestra Jurnal Kehutanan 11:2

Heyne K. 1950. Beneficial plants of Indonesia. Translated in 1987. Sarana Wana Jaya, Jakarta.

Howe HF, Smallwood J. 1982. Ecology of seed dispersal. Ann Rev Ecol Syst 13: 201-228

Husen R, Pihie AHL, Nallappan M. 2004. Screening for antihyperglycaemic activity in several local herbs of Malaysia. J. Ethnopharmacol. 95: 205-208. 
Hussein S, Ibrahim R, LingPick K. 2007. A summary of reported chemical constituents and medicinal uses of Eurycoma longifolia. J Trop Med Plants8:: 103-110.

Jiwajinda S, Santisopasri V, Murakami A, Hirai N, Ohigashi H. 2001. Quassinoids from Eurycoma longifolia as plant growth inhibitors. Phytochemistry 58: 959-962.

Johns AD. 1988. Effects of selective timber extraction on rainforest structure and composition and some consequences for frugivores and folivores. Biotropica 20: 31-37.

Kardono LB, Angerhofer CK, Tsauri S, Padmawinata K, Pezzuto JM, Kinghorn AD. 1991. Cytotoxic and antimalarial constituents of the roots of Eurycoma longifolia. J Nat Prod 54: 1360-1367.

Kartikawati SM, Zuhud EAM, Hikmat A, Kartodihardjo H, Fuadi M. 2014. Habitat preference, distribution pattern and root weight estimation of Pasak bumi (Eurycoma longifolia Jack). J Trop For Management 20 (1): 43-50

Keng H, Keng RSL. 1990. The concise flora of Singapore: gymnosperms anddicotyledonss; Singapore University Press: Kent Ridge, Singapore.

Kong C, Yehye WA, Rahman NA, Tan MW, Nathan S. 2014. Discovery of potential anti-infectives against Staphylococcus aureus using a Caenorhabditis elegans infection model. BMC Compl Altern Med 14: 4. DOI: $10.1186 / 1472-6882-14-4$

Kuo PC, Damu AG, Lee KH, Wu TS. 2004. Cytotoxic and antimalarial constituents from the roots of Eurycoma longifolia. Biorg. Med. Chem. 12, 537-544.

Lahrita L, Kato E, Kawabata J. 2015. Uncovering potential of Indonesian medicinal plants on glucose uptake enhancement and lipid suppression in 3T3-L1 adipocytes. J Ethnopharmacol 168: 229-236.

Lazuriaga AL, Escudero A, Albert MJ, Gimenez-Binavides L. 2006. Population structure effect on reproduction of a rare plant: beyond population size effect. Canadian J Bot. 84: 1371-1379.

Low BS, Das PK, Chan KL. 2013. Standardized quassinoid-rich Eurycoma longifolia extract improved spermatogenesis and fertility in male rats via the hypothalamic-pituitary-gonadal axis. J. Ethnopharmacol 145: 706-714.

Melton LJ, Chrischilles EA, Cooper C, Lane AW, Riggs BL. 2005. How many women have osteoporosis ?. Bone Mine. Re. 20: 886-892
Nathan R, Muller-Landau H. 2000.) Spatial patterns of seed dispersal, their determinants and consequences for recruitment. Trends in Ecol and Evolution, 15: 278-285.

Odum EP. 1971.Fundamentalsl of Ecology. W.B. Sounders Company. Philadelphia.

Okuda T, Kachi N, Yap SK, Manokaran N. 1997. Tree distribution pattern and fate of juveniles in a lowland tropical rain forest-implications for regeneration and maintenance of species diversity. Plant Ecol 131: $155-171$

Padua LS de. 1999. Plant Resources of South East Asia. Bibliography 12:Medicinall Plant. Prosea Foundation, Bogor.

Patwardhan B, Vaidya AD, Chorghade M. 2004. Ayurveda and natural products drug discovery. Curr Sci Bangalore 86: 789-799.

Saniga M, Balanda M. 2008. Dynamics of tree species composition and characteristics of available space utilization in the natural forest of the National Nature Reserve Hrončokovský Grúň. J For Sci 54: 497-508

Tran TVA, Malainer C, Schwaiger S, Atanasov AG, Heiss EH, Dirsch VM, Stuppner H. 2014. NF-inhibitors from Eurycoma longifolia. J Nat Prod 77: 483-488.

Teh CH, Abdulghani M, Morita H, Shiro M, Hussin AH, Chan KL. 2011. Comparative X-ray and conformational analysis of a new crystal of 13_,21-dihydroeurycomanone with eurycomanone from Eurycoma longifolia and their anti-estrogenic activity using the uterotrophic assay. Planta Medica 77: 128-132

Wernsdorfer WH, Ismail S, Chan KL, Congpuong K, Wernsdorfer G. 2009. Activity of Eurycoma longifolia root extract against Plasmodium falciparum in vitro. Wien. Klinische Wochenschr 121: 23-26.

Wilsey B, Stirling G. 2007. Species richness and evenness respond in a different manner to propagule density in developing prairie microcosm communities. Plant Ecol 190: 259-273

Zulfahmi, Nelawati, Rusmaina. 2015. Kepadatan dan pola penyebaran pasak bumi (Eurycoma longfolia Jack.) di Zona Alaman Kuyang, Hutan Larangan Adat Kenegarian Rumbio. J Agrotechnol 6 (1): 4146. [Indonesian] 